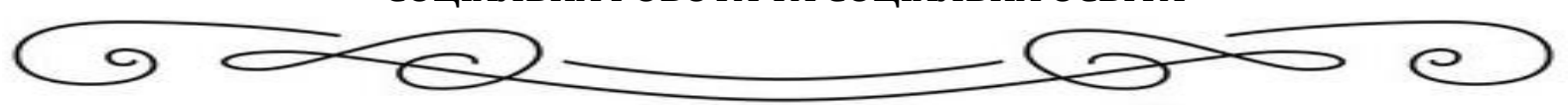

УДК 061.2-053.67:316.621]34

DOI: 10.31499/.3.2019.190418

\title{
МОЛОДІЖНІ ГРОМАДСЬКІ ОРГАНІЗАЦІЇ ЯК ЧИННИК ФОРМУВАННЯ СОЦІАЛЬНОЇ АКТИВНОСТІ МОЛОДІ: ПРАВОВІ ЗАСАДИ
}

Левченко Наталія, кандидат педагогічних наук, доцент кафедри соціальної педагогіки та соціальної роботи, Уманський державний педагогічний університет імені Павла Тичини.

ORCID: 0000-0002-5479-1907

E-mail: n.levchenkod@gmail.com

Калюженко Аліна, магістрант факультету соціальної та психологічної освіти, Уманський державний педагогічний університет імені Павла Тичини.

ORCID: 0000-0002-6870-6312

E-mail: alinakaliuzhenko@gmail.com

у статті представлено особливості та специфіку роботи молодіжних громадських організацій як чинник формування соціальної активності молоді; визначено поняття «громадські об'єднання», «члени молодіжної громадської організації», «принципи утворення $i$ діяльності молодіжних та дитячих громадських організацій»; виділено основні функції громадських організацій; розкрито особливості, основні цілі та завдання роботи молодіжних організацій м. Умані. Здійснено аналіз активності молодіжних рад, які здійснюють свою діяльність при відділі у справах сім'ї та молоді Уманської міської ради.

Ключові слова: молодь, молодіжна політика, громадські організації, молодіжні та дитячі громадські організації, соціалізація, Молодіжна рада, самореалізація, активність.

\section{YOUTH NGOS AS A FACTOR IN THE FORMATION OF YOUTH SOCIAL ACTIVITY: LEGAL BASIS}

Levchenko Nataliia, $\mathrm{PhD}$ in Pedagogical Sciences, Associate Professor of the Department of Social Pedagogy and Social Work, Pavlo Tychyna Uman State Pedagogical University.

ORCID: 0000-0002-5479-1907

E-mail: n.levchenkod@gmail.com

Kaliuzhenko Alina, Master of the Faculty of Social and Psychological Education, Pavlo Tychyna Uman State Pedagogical University.

ORCID: 0000-0002-6870-6312

E-mail: alinakaliuzhenko@gmail.com

The article presents the peculiarities and specifics of the work of youth public organizations as a factor in the formation of youth social activity. It defines the concepts of "public associations", "members of youth public organizations", "principles of formation and activity of youth and children's public organizations"; and highlights the main functions of public organizations. Moreover, the study reveals the peculiarities, main goals and tasks of youth public organizations 


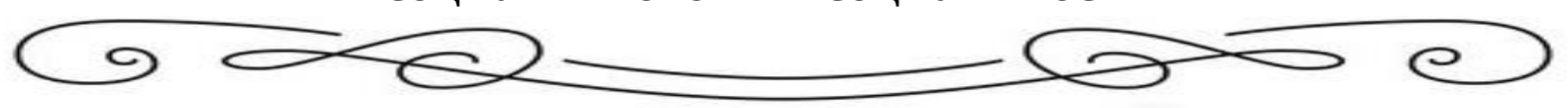

in Uman.

The activity of youth councils, which operate in the department of family and youth affairs of the Uman City Council, is analyzed.

The purpose of the article is to characterize the legal foundations of the organization and activity of youth NGOs, as a factor in shaping youth social activity.

The process of establishing a civil society in Ukraine is objectively linked to certain difficulties, among which is the lack of legal regulation of one of the main institutions of civil society - public organizations.

Youth NGOs influence the socialization of the individual directly and indirectly, namely as members of the youth NGO itself, as well as those with whom the organization is affiliated or cooperates. These may be educational institutions, children's and youth organizations or other partners.

To conclude, youth NGOs as social institutions are characterized by diverse activities, quantitative and qualitative composition, and status. Such organizations implement social projects, involve partners in socially significant activities, take part in the work of public councils at state authorities, and generally gain experience of cooperation with other institutions.

Keywords: youth, youth policy, public organizations, youth and children's public organizations, socialization, Youth Council, self-realization, activity.

В Україні впродовж останніх років створено значну кількість молодіжних громадських організацій, які діють на засадах добровільності, рівноправності їхніх членів, самоврядування, законності та гласності. Розширився вплив громадськості на владу, члени недержавних організацій входять до громадських та експертних рад при органах державної влади, їх залучають до розроблення заходів 3 молодіжної політики, виконання соціальних проєктів тощо.

Розвиток суспільства значною мірою залежить від того, чи використовується такий дієвий фактор суспільно-політичного функціонування, як молодіжні громадські організації в процесі державоутворення і побудови справжнього громадянського суспільства, тому молодіжні громадські організації $\epsilon$ посередниками між молоддю і державою. Взагалі держава підтримує діяльність тих, які конструктивно працюють у межах існуючого законодавства, стимулює розвиток молодіжного руху в цілому. Завдяки діяльності громадських організацій громадяни мають можливість ефективно взаємодіяти 3 органами державної влади та впливати на їх рішення, а відтак визначати їх легітимний характер.

У зв'язку з актуальністю означеної проблеми діяльність молодіжних громадських організацій аналізувалася вченими в різних аспектах: соціальнопедагогічна діяльність сучасних громадських молодіжних об'єднань в Україні (Ю.Поліщук); соціалізація підлітків в діяльності молодіжних організацій (О.Панагушина); організаційно-педагогічні умови соціалізації підлітків в неформальних молодіжних об'єднаннях (С. Чернета); юридичний аспект висвітлювали (О.Петришина, І. Коваль, В. Федоренко, А. Колодій); підготовка соціальних педагогів до роботи з молодіжними організаціями (О. Лісовець); формування лідерських якостей особистості у діяльності студентських громадських об'єднань (Л. Ніколенко); трудова соціалізація молоді в діяльності громадських організацій та рухів (Ю. Філіппов); соціально-педагогічна діяльність студентських волонтерських груп (Т. Лях) та ін.

Мета статті - охарактеризувати правові засади організації та діяльності молодіжних громадських організацій, молодіжні громадські організації, як чинник 


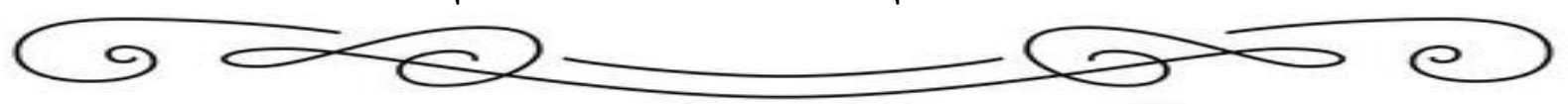

формування соціальної активності молоді.

Державною молодіжною політикою визначається системна діяльність держави у відносинах 3 особистістю, молоддю, молодіжним рухом, що здійснюється у законодавчій, виконавчій, судовій сферах і ставить за ціль створення соціально-економічних, політичних, організаційних, правових умов та гарантій для життєвого самовизначення, інтелектуального, морального, фізичного розвитку молоді, реалізації ï творчого потенціалу як у власних інтересах, так і в інтересах України.

Молодіжна політика стала одним із найважливіших напрямів діяльності органів державної влади з перших років незалежності України, тому 15 грудня 1992 р. Верховна Рада України прийняла Декларацію «Про загальні засади державної молодіжної політики в Україні», а 5 лютого 1993 р. Закон України «Про сприяння соціальному становленню та розвитку молоді в Україні», що визначає загальні засади створення організаційних, соціально-економічних, політикоправових умов соціального становлення та розвитку молоді, основні напрями реалізації державної молодіжної політики в Україні [8, с. 47].

Процес становлення громадянського суспільства в Україні об'єктивно пов'язаний із певними труднощами, серед яких - недостатнє правове регулювання одного із основних інститутів громадянського суспільства громадських організацій.

Основним інститутом i ознакою громадянського суспільства можна вважати добровільні громадські організації, основні засади й орієнтири регулювання суспільних відносин у сфері утворення, реєстрації та їх функціонування окреслені в ряді Законів України «Про сприяння соціальному становленню та розвитку молоді в Україні», «Про громадські об'єднання», «Про молодіжні та дитячі громадські організації», «Про об’єднання громадян» та інших галузевих документах і матеріалах щодо реалізації молодіжної політики в Україні $[3$, c. 256].

Згідно до Закону України «Про громадські об’єднання», громадські об'єднання - це добровільне об'єднання фізичних та/або юридичних осіб приватного права для здійснення та захисту прав і свобод, задоволення суспільних, зокрема економічних, соціальних, культурних, екологічних та інших інтересів. Головними ознаками таких об'єднань $€$ їх недержавний, неприбутковий, добровільний та самоврядний характер. Право на об'єднання $є$ одним із невід'ємних прав людини, що закріплено в багатьох міжнародно-правових документах [5].

Відповідно до чинного законодавства, держава повинна забезпечувати дотримання прав громадських об'єднань. Конституція України (стаття 36), гарантує та захищає це право відповідно до міжнародних стандартів. Право на свободу об’єднання забезпечує проголошену ст. 15 Конституції економічну, політичну та ідеологічну багатоманітність у суспільному житті та свободу політичної діяльності. Свобода об'єднань означає правову і фактичну можливість добровільно, без примусу чи попереднього дозволу, утворювати об'єднання громадян або вступати до них. Метою утворення громадських організацій $є$ захист 


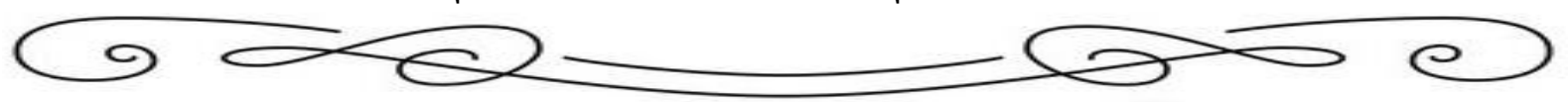

прав і свобод, задоволення економічних, соціальних, культурних та інших інтересів [1, с. 12].

Особливий вплив має Закон України «Про молодіжні та дитячі громадські організації». Відповідно до цього Закону, членами молодіжних громадських організацій можуть бути громадяни віком від 14 до 35 років, кількість осіб старшого віку у цих організаціях не може перевищувати 10 відсотків загальної кількості членів. Засновниками молодіжної громадської організації можуть бути громадяни України, іноземці та особи без громадянства [5].

Згідно ст. 3 Закону України «Про молодіжні та дитячі громадські організації» Принципи утворення i діяльності молодіжних та дитячих громадських організацій молодіжні та дитячі громадські організації утворюються і діють на засадах добровільності, рівноправності їх членів, самоврядування, законності та гласності, зокрема:

- молодіжні та дитячі громадські організації зобов'язані доводити до відома громадськості відомості про свою діяльність у формах, що не суперечать законодавству;

- інформація, що міститься у статутах, про склад керівних органів, про джерела матеріальних та інших надходжень, а також пов'язана 3 діяльністю молодіжних та дитячих громадських організацій, не $\epsilon$ конфіденційною або іншою інформацією, яка охороняється законом.

Аналізуючи діяльність молодіжних громадських організацій, необхідно підкреслити їхню надзвичайно вагому роль у набутті молоддю самостійності, самовизначенні, самоствердженні, соціалізації. На цьому, зокрема, наголошує С. Харченко, який вважає їхню діяльність невід'ємною у різних сферах життя країни. Важливо, що громадські об'єднання залучаються до формування і реалізації державної політики, вирішення питань місцевого значення. Передбачається також право громадських об'єднань звертатися до органів державної влади, органів місцевого самоврядування, їхніх посадових i службових осіб 3 пропозиціями, заявами, скаргами, що відповідає статті 40 Конституції України $[12$, с. 320].

Завдяки створенню молодіжними громадськими організаціями системи соціальних зв'язків і відносин, їх члени мають можливість засвоїти позитивний соціальний досвід, формують соціально значущі установки, уміння про соціальної поведінки. Завдяки цьому забезпечується успішність соціалізації молодої людини.

Діяльність молодіжних громадських організацій як одного 3 багатьох інститутів соціального впливу на особистість вирізняється певними ознаками, a came:

- наявність мети;

- структурованість;

- система цінностей;

- набір соціальних позицій та ролей тощо.

Для розуміння характеру впливу таких об'єднань на підростаючу особистість молодіжні громадські організації можна за характером поділити на такі види діяльності, а саме: 


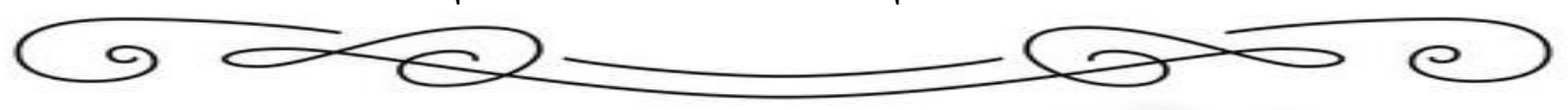

- молодіжні філії політичних партій;

- громадсько-політичні організації молоді;

- молодіжні релігійні організації;

- молодіжні фахові об'єднання;

- організації за інтересами;

- благодійні фонди;

- національні молодіжні організації;

- молодіжні партії;

- студентські організації.

Своєю чергою, студентські організації бувають профспілкові, громадські та фахові. Саме студентські громадські організації можуть стати ключовим інститутом формування соціальної активності студентів. Ці організації мають свою специфіку серед інших громадських об'єднань відповідно до особливостей соціального стану їхніх членів, мети та організаційно-педагогічних умов [3, с. 257].

Основними мотивами вступу юнаків і дівчат до молодіжних організацій $\epsilon$ такі: цікаво проводити дозвілля; самореалізовуватися та самостверджуватися серед однолітків; розширювати коло спілкування; змінити власне життя на краще, сприяти розвитку України [2, с. 314].

Молодіжні громадські організації впливають на соціалізацію особистості прямо і опосередковано, а саме як на членів самої молодіжної громадської організації, так і на тих, з ким організація пов'язана або співпрацює. Це можуть бути заклади освіти, дитячі та молодіжні організації чи інші партнери. На цьому акцентують багато вчених. Так, Ю. Поліщук зазначає, що саме в процесі взаємодії 3 різними соціальними інститутами у особистості накопичуються відповідні знання і досвід соціально схвалюваної поведінки [10, с. 42].

Дослідники вважають, що громадські організації виконують такі функції: переважно професійної, громадянської соціалізації; функцію комунікації; окремі реалізують нормативно-регулятивну функцію.

Розкриваючи характер функціонування молодіжних громадських організацій в Україні дослідники звертають увагу ще на такі функції: організаційну, виховну, комунікативну, господарську. Організаційна функція здебільшого пов'язана з навчанням вмінню жити в колективі, звіряючи свої інтереси з інтересами і потребами інших людей, всього колективу в цілому. Виховна виявляється у тому, що в організації не вимірюються інтереси конкретної особистості, а поширюється вплив людей одне на одного. Комунікативна ж пов'язана з безпосереднім спілкуванням людей, які перебувають в одній організації. Господарська функція передбачає участь молодіжних організацій у вирішенні як особистих так і народногосподарських завдань.

Крім названих функцій важливе значення мають такі функції як опозиційна, захисна, виховна, кадрова. Суть опозиційної функції полягає у сприянні розвитку громадянського суспільства шляхом оприлюднення свого ставлення до державних рішень, висування нових ідей, розробки програм тощо. Захисна функція включає захист потреб і інтересів членів молодіжних громадських організацій через вияв законодавчих ініціатив, внесення 


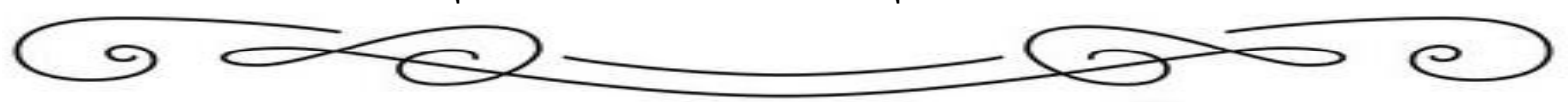

альтернативних пропозицій тощо. Вона спрямована на захист інтересів і потреб членів організації через вимоги, подання заяв до державних органів, контроль за виконанням своїх рішень і угод 3 державними органами, установами тощо. Виховна функція полягає у формуванні в громадян моральної, політичної, політичної, управлінської, правової культури, національної свідомості, відповідальності за свою поведінку, трудову дисципліну і т.п. У їі забезпеченні вагоме місце посідають методи переконання, заохочення, залучення до підприємницької, громадської, управлінської та інших видів діяльності. Кадрова функція в своїй основі містить підготовку кваліфікованих кадрів для державних та громадських структур. Нинішні фахівці відзначають відзначають той факт, що «... на сучасному етапі в демократичних суспільствах громадські об'єднання перебирають на себе все більше функцій державних установ, здійснюють громадський контроль над ними, впливаючи на державну політику і розвиток суспільства загалом» [9, с. 582].

Функції можуть трансформуватися і доповнюватися залежно від цілей конкретної організації.

Відповідно до функцій, ключовими напрямами діяльності молодіжних громадських організацій можуть бути: волонтерство, громадянське виховання, сприяння розвитку молодіжного підприємництва, туризм, міжнародний обмін, народна творчість тощо.

Завдяки активності молодіжних громадських організацій при обласних державних адміністраціях створюють також молодіжні ради, до яких входять, крім лідерів молодіжних громадських організацій, представники органів студентського самоврядування. У деяких містах молодіжні ради діють при відділі у справах сім'ї та молоді [11, с. 22].

Так, у м. Умані діє молодіжна громадська організація «Академія молодіжного лідера», яка спрямована на виховання нового покоління лідерів, підвищення професійної освіти молоді, сприяння талановитим студентам та аспірантам у набутті адміністративного та управлінського досвіду шляхом їх роботи у органах місцевого самоврядування. «Академія молодіжного лідера» виокремлює такі цілі та завдання:

- здійснення підготовки нового покоління лідерів, управлінців, менеджерів для м. Умані;

- ознайомлення учасників проєкту із законодавчою та нормативною базою органів місцевого самоврядування;

- сприяння підвищенню професійних знань, кваліфікації молоді;

- сприяння налагодженню діалогу між владою та молоддю;

- створення Банку суспільно-корисних ініціатив.

У відділі у справах сім'ї та молоді Уманської міської ради чітко реалізовується кожний напрям роботи та здійснюється великий об'єм роботи.

Відділ сприяє розвитку молодіжної політики в місті, у 2018 році місто Умань, серед перших 11 міст та громад України, отримало статус кандидата на звання Громади дружньої до дітей та молоді в рамках проєкту, що реалізовується Дитячим фонду ООН (ЮНІСЕФ). 


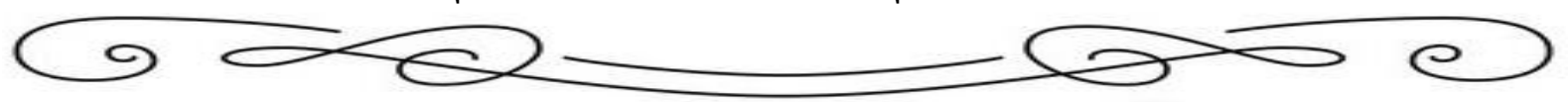

У 2018 році створено консультативно-дорадчий орган Молодіжна рада, до складу якої увійшли представники молодіжних та дитячих організацій, студентських рад, молодь з активною громадянською позицією.

Молодіжна рада при виконавчому комітеті Уманської міської ради (далі Молодіжна рада) $€$ консультативно-дорадчим органом 3 питань молодіжної політики, покликаним сприяти взаємодії міської влади та молоді міста Умані, забезпечувати узгодженість дій у вирішенні питань, пов'язаних із життям молоді та їі участю в усіх сферах життя суспільства, проведенням інформаційнонавчальної роботи серед молоді та консолідації молодіжного руху міста.

Метою Молодіжної ради $є$ можливість молоді міста взяти безпосередню участь як у формуванні міської політики з питань, які впливають на ї̈ життя, так і в процесах прийняття певних рішень, набути досвіду роботи в органах місцевого самоврядування, що забезпечить створення передумов для їх особистісного, професійного зростання і успішної суспільно-політичної діяльності.

Основними завданнями Молодіжної ради $є:$

1) залучення молоді до участі у громадському житті міста шляхом розробки та реалізації молодіжних програм;

2) поширення серед молоді волонтерського руху, спрямованого на поліпшення соціального становища та життя молоді міста;

3) підготовка для міського голови пропозицій щодо проведення роботи 3 молодими людьми з питань молодіжної політики;

4) визначення та обгрунтування пріоритетних напрямів молодіжної політики;

5) інформування громадськості, зокрема через засоби масової інформації, про свою діяльність, прийняті рішення та стан їх виконання;

6) сприяння врахуванню органом місцевого самоврядування громадської думки під час формування та реалізації державної молодіжної політики;

7) сприяння патріотичному вихованню та підвищенню рівня національної свідомості молоді;

8) розвиток всебічних зв'язків молоді міста з молодіжними організаціями;

9) інші завдання, які не суперечать законодавству України.

Молодіжна рада працюює в таких напрямах:

- культура та дозвілля;

- розвиток студентського самоврядування;

- фізична культура та спорт;

- волонтерський рух.

Отже, молодіжні громадські організації як соціальні інститути вирізняються різноплановою діяльністю, кількісним і якісним складом, статусом. Такі організації реалізують соціальні проєкти, залучають до соціально значущої діяльності партнерів, беруть участь у роботі громадських рад при державних органах влади, загалом отримують досвід взаємодії з іншими інституціями. Враховуючи зазначене, $є$ усі підстави вважати молодіжні громадські організації інститутами формування соціальної активності підростаючої особистості. Одним із зобов'язань держави стосовно громадських організацій $\epsilon$ нормативно-правове 


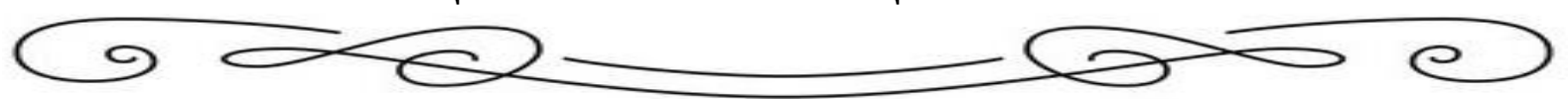

забезпечення їх діяльності та взаємодії з органами публічної влади, зокрема прийняття спеціальних законів, які визначають їх правовий статус (Закону «Про громадські правозахисні організації» та нових редакцій Законів «Про професійні спілки, їх права та гарантії діяльності», «Про свободу совісті та релігійні організації»). Нормативно-правове регулювання діяльності громадських організацій з боку держави не повинно суперечити базовим засадам демократії. Межі правового впливу в демократичній правовій державі повинні визначатися свободою, справедливістю, невідчужуваними правами людини, самоврядністю, реалізацією загальнодозвільних принципів.

\section{СПИСОК ВИКОРИСТАНИХ ДЖЕРЕЛ}

1. Конституція України. Науково-практичний коментар / редкол.: В. Я. Тацій (голова редкол.), О. В. Петришин, Ю. Г. Барабаш та ін.; Нац. акад. прав. наук України. 2-ге вид., переробл. і допов. Харків: Право, 2011.12 с.

2. Криворучко Ю. Молодь як суспільний чинник формування громадянського суспільства України. Громадянське суспільство як здійснення свободи: центральносхідноєвропейський досвід /за ред. А. Карася. Львів, 2009.

3. Лісовець О.В. Теорія і методика роботи з дитячими та молодіжними організаціями України: навч. посіб. Київ: Академія, 2011. 256 с.

4. Про громадські об’єднання: закон України від 22.03 .2012 p. № 4572-VI. URL: https://zakon.rada.gov.ua/laws/show/4572-17 (дата звернення 11.047.2019).

5. Про молодіжні та дитячі громадські організації: закон України від 01.01.2016 p. № 835-VIII. URL: https://zakon.rada.gov.ua/laws/show/281-14 (дата звернення 12.04.2019).

6. Про об'єднання громадян: закон України: від 16.06.1992 p. 2460-XII. URL: https://zakon. rada.gov.ua/laws/show/2460-12 (дата звернення 12.04.2019).

7. Про сприяння соціальному становленню та розвитку молоді в Україні: закон України від 04.11.2018 № 2581-VIII. URL: https://zakon.rada.gov.ua/laws/show/2998-12 (дата звернення 12.04.2019).

8. Макарова О. В. Програми соціальної підтримки: оцінка результатів та шляхи удосконалення. Демографія та соціальна економіка. 2014. № 1(21).

9. Політологія: підручник / ред. О. В. Бабкіна, В. П. Горбатенко. Київ: Академія, 2003. 528 с.

10. Поліщук Ю. Й. Соціально-педагогічна діяльність сучасних громадських молодіжних об'єднань в Україні: автореф. дис. ... д-ра пед. Наук: 13.00.05. Луганськ, 2006. 42 с.

11. Розвиток громадянського суспільства в Україні / укл. Л. Шара, І. Підлуська та ін. Київ, 2002. $22 \mathrm{c}$.

12. Харченко С. Я. Соціалізація дітей та молоді в процесі соціально-педагогічної діяльності: теорія і практика: монографія / С. Я. Харченко. Луганськ: Альма-матер, 2006. 320 с.

\section{REFERENCES}

1. Konstytutsiia Ukrainy. Naukovo-praktychnyi komentar. (2011). V. Ya. Tatsii, O. V. Petryshyn, Yu. H. Barabash ta in. Kharkiv: Pravo [in Ukrainian].

2. Kryvoruchko, Yu. (2009). Molod yak suspilnyi chynnyk formuvannia hromadianskoho suspilstva Ukrainy. Hromadianske suspilstvo yak zdiisnennia svobody: tsentralnoskhidnoievropeiskyi dosvid. A. Karasia (Ed.). Lviv [in Ukrainian].

3. Lisovets, O. V. (2011). Teoriia i metodyka roboty z dytiachymy ta molodizhnymy orhanizatsiiamy Ukrainy. Kyiv: Akademiia [in Ukrainian].

4. Pro hromadski ob'iednannia: zakon Ukrainy vid $22.03 .2012 \mathrm{r}$. № 4572-VI. URL: https://zakon.rada.gov.ua/laws/show/4572-17 [in Ukrainian].

5. Pro molodizhni ta dytiachi hromadski orhanizatsii: zakon Ukrainy vid 01.01.2016 r. № 835-VIII. URL: https://zakon.rada.gov.ua/laws/show/281-14 [in Ukrainian].

6. Pro ob'iednannia hromadian: zakon Ukrainy: vid $16.06 .1992 \mathrm{r}$. 2460-XII. URL: 


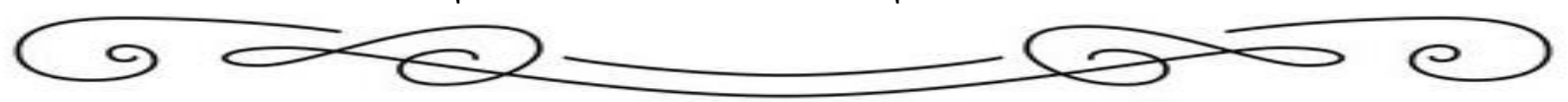

https://zakon.rada.gov.ua/laws/show/2460-12 [in Ukrainian].

7. Pro spryiannia sotsialnomu stanovlenniu ta rozvytku molodi $v$ Ukraini: zakon Ukrainy vid 04.11.2018 No 2581-VIII. URL: https://zakon.rada.gov.ua/laws/show/2998-12 [in Ukrainian].

8. Makarova, O.V. (2014). Prohramy sotsialnoi pidtrymky: otsinka rezultativ ta shliakhy udoskonalennia. Demohrafiia ta sotsialna ekonomika, 1(21) [in Ukrainian].

9. Politolohiia: pidruchnyk. (2003). O.V. Babkina, V.P. Horbatenko (Ed.). Kyiv: Akademiia [in Ukrainian].

10. Polishchuk, Yu. Y. (2006). Sotsialno-pedahohichna diialnist suchasnykh hromadskykh molodizhnykh ob'iednan v Ukraini. Extended abstract of doctor's thesis. Luhansk [in Ukrainian].

11. Rozvytok hromadianskoho suspilstva v Ukraini. (2002). L. Shara, I. Pidluska ta in. (Eds.). Kyiv [in Ukrainian].

12. Kharchenko, S. Ya. (2006). Sotsializatsiia ditei ta molodi v protsesi sotsialno-pedahohichnoi diialnosti: teoriia i praktyka. Luhansk: Alma-mater [in Ukrainian]. 